\title{
A STUDY OF PERINEURAL AND LYMPHOVASCULAR SPACE INVASION IN INVASIVE CARCINOIMA BREAST PATIENTS
}

KEY WORDS: Breast carcinoma, perineural invasion, Lympho vascular space invasion, prognosis in carcinoma breast

\section{S.Marimuthu*}

\section{P Muniyasamy}

Department of Surgical Oncology. Thanjavur Medical College, Thanjavur, Tamilnadu, India. *Corresponding Author

Department of Surgical Oncology. Thanjavur Medical College, Thanjavur, Tamilnadu, India.

OBJECTIVES: To know the Perineural and lymphovascular space invasion in early operable breast cancer patients since these are prognostic factors in patient's invasive carcinoma breast.

Methods: In this present study, Perineural and lymphovascular space invasion was studied pathologically in postmastectomy specimens in 134 patients.

RESULTS: In this study, 6 (4.48\%) patients had perineural invasion and 2 (1.49\%) patients had only perineural invasion without lymphovascular space invasion. 19(14.18\%) patients had lymphovascular space invasion and 15 (11.2\%) patients had lymphovascular space invasion alone without perineural invasion. $4(3 \%)$ patients had both lympho vascular space invasion alone and perineural invasion.

CONCLUSION: Lympho vascular space invasion, which impact the prognosis adversely, is present in $15 \%$ of the patients with invasive carcinoma breast.

\section{INTRODUCTION:}

Invasive breast cancer is the most commonly occurring cancer in female patients all over the world. Patients were presented for treatment in late stages in the past. Now with increasing awareness, they are coming treatment early. $\mathrm{T}$ (tumor), $\mathrm{N}$ (node), $\mathrm{M}$ (metastasis) classification is used now for staging in these patients. Lympho vascular space invasion (LVSI) $(2,3)$ is a poor prognostic feature in Invasive breast cancer. Perineural invasion (PNI), a sign of aggressive behavior potential in other tumor systems, is less frequently observed in mammary carcinoma and hence has been less well studied. This study was conducted to know the frequency of PNI and LVSI in mammary carcinoma and to describe the relationships between PNI, tumor characteristics like grade and nodal status.

\section{MATERIALS AND METHODS.}

Records of 134 Consecutive modified Radical Mastectomies were analyzed. These mastectomies were done for early operable breast cancer patients with mobile axillary lymph nodes or clinically node negative disease. Mastectomy after Neo-adjuvant chemotherapy, Palliative Mastectomy and Mastectomy in Stage 4 patients were excluded. After Mastectomy, careful Bench dissection of axillary nodes were done immediately after surgery by operating surgeon in the operation theatre itself with good light. With careful palpation and dissection of axillary fat, Breast tail, all palpable nodes were completely removed, put into the container with formalin and send to the pathologist with proper labeling, history and requisition.

\section{RESULTS:}

\section{Incidence of LVSI and PNI}

Out of 134 patients, $6(4.48 \%)$ patients had PNI. Out of which, 2 patients had only PNI and 4 patients had PNI and LVSI. 19 (14.18\%) patients had LVSI. Out of which, 15 patients had only LVSI. (tablel).

Study by Soma Ghosh Karak et al (1)in 2010 (Table 2) showed, out of 1136 patients, 146(12.9\%) patients had LVSI (our study $14.18 \%$ ) and $13(1.14 \%$ ) patients had PNI (our study $4.48 \%$ )

\section{Table 1:- Incidence of PNI and LVSI}

\begin{tabular}{|l|l|l|l|l|l|}
\hline & $\begin{array}{l}\text { PNI } \\
\text { alone }\end{array}$ & $\begin{array}{l}\text { PNI } \\
\text { TOTAL }\end{array}$ & $\begin{array}{l}\text { LVSI } \\
\text { ALONE }\end{array}$ & $\begin{array}{l}\text { LVSI } \\
\text { TOTAL }\end{array}$ & $\begin{array}{l}\text { BOTH } \\
\text { PNI\&LVSI }\end{array}$ \\
\hline No of patients & 2 & 6 & 15 & 19 & 4 \\
\hline $\begin{array}{l}\text { TOTAL PTIENT } \\
\text { STUDIED }\end{array}$ & 134 & 134 & 134 & 134 & 134 \\
\hline
\end{tabular}

\begin{tabular}{|l|l|l|l|l|l|}
\hline $\begin{array}{l}\% \text { OF } \\
\text { OCCURRENCE }\end{array}$ & $1.49 \%$ & $4.48 \%$ & $11.2 \%$ & $14.18 \%$ & $3 \%$ \\
\hline
\end{tabular}

Table 1:- Incidence of PNI and LVSI:This study Vs Soma Ghosh Karak et al 2010

\begin{tabular}{|l|c|c|c|c|c|c|}
\hline TOTAL & $\begin{array}{c}\text { Present } \\
\text { PATIENTS } \\
\text { POSITIV } \\
\text { E }\end{array}$ & $\begin{array}{c}\text { Present } \\
\text { study } \\
\%\end{array}$ & $\begin{array}{c}\text { TOTAL } \\
\text { PATIENT } \\
\text { S }\end{array}$ & $\begin{array}{c}\text { Soma } \\
\text { Ghosh } \\
\text { Karak et } \\
\text { al. }\end{array}$ & $\begin{array}{c}\text { Soma } \\
\text { Ghosh } \\
\text { Karak et } \\
\text { al. } \%\end{array}$ \\
\hline LVSI & 134 & 19 & $14.18 \%$ & 1136 & 146 & $12.9 \%$ \\
\hline PNI & 134 & 6 & $4.48 \%$ & 1136 & 13 & $1.14 \%$ \\
\hline
\end{tabular}

\section{LVSI and Age distribution}

Out of 136 of patients, $13(72.4 \%$ ) (Table 3 ) patients are in the age group of 40 to 60years. Only one patient is age below 40 years.

Table 3:- LVSI and Age distribution

\begin{tabular}{|l|l|l|}
\hline Age & NO OF PATIENTS & PERCENTAGE \\
\hline$<40$ & 1 & $5.26 \%$ \\
\hline $40-<50$ & 6 & $35.60 \%$ \\
\hline $50-<60$ & 7 & $36.80 \%$ \\
\hline $60-<70$ & 2 & $10.52 \%$ \\
\hline$>70$ AND MORE & 3 & $15.79 \%$ \\
\hline Total & 19 & $100 \%$ \\
\hline
\end{tabular}

Table 4:-LVSI and Grade of tumor-comparison

\begin{tabular}{|l|l|l|}
\hline Grade of tumour & No of Patients & Percentage \\
\hline Gradel & 2 & $10.79 \%$ \\
\hline Grade 2 & 16 & $84.21 \%$ \\
\hline Grade3 & 1 & $5.26 \%$ \\
\hline Total & 19 & $100 \%$ \\
\hline
\end{tabular}

Table 5:- LVSI and Nodal Stage - comparison

\begin{tabular}{|l|l|l|}
\hline Nodal stage & No of Patients & Percentage \\
\hline N0 disease & 2 & $10.53 \%$ \\
\hline N1 Disease & 3 & $15.79 \%$ \\
\hline N2 Disease & 9 & $43.37 \%$ \\
\hline N3 Disease & 5 & $26.32 \%$ \\
\hline & 19 & $100 \%$ \\
\hline
\end{tabular}

LVSI and grade of tumor and Nodal stage

Out of 19 patients with LVSI, most of the patients, $16(84.21 \%)$ patients had grade 2 tumor. 17(89.475) patients had node positive disease

\section{DISCUSSION:}

Breast cancer peaks in the age of 50-60Years and three fourth 
of patients are $40-70$ years old. Even though $40 \%$ present with N0 disease, still $60 \%$ of patients had Node positive disease. Significant percentage of Patients (37.3\%) had TNM stage 3 disease indicating locally advanced breast cancer with poor prognosis. Patients with LVSI are associated with local recurrence and reduced survival [4]. Significant percentage $(14.18 \%)$ (19 out of 136) of patients had Lympho-vascular space invasion indicating poor prognosis. In this, 17 out of 19 patients with LVSI had nodal metastases indicating LVSI is the predictor of Nodal metastases.

Perineural invasion (PNI) is infrequeninfrequently observed in invasive breast carcinoma, occurring in approximately $1 \%$ of cases, perhaps in part because nerves of notable size are not numerous in mammary tissues. Tumor characteristics associated with PNI include higher T-stage, higher tumor grade and LVSI. In our study PNI was $4 \%$. It tends to occur in high-grade tumors, where it is frequently associated with LVSI, but it has not been proven to have independent prognostic significance [5-8].

\section{CONCLUSION:}

LVSI is the predictor of Nodal metastases, so indicator of poor prognosis. PNI is a relatively rare histological feature in invasive breast carcinoma occurring 10 times less frequently than LVI, its role as an independent poor prognostic feature remains questionable. Our patients need early detection to improve prognosis and survival by way of health education, awareness regarding breast cancer and screening.

\section{Acknowledgment}

The authors wish to thank MD.Sangeetha, S Amirthavalli and Jessipriya for assistance in statistical evaluation preparation of manuscript.

\section{CONFLICT OF INTERESTS}

Declare none

\section{REFERENCES}

1. Prevalence and significance of perineural invasion in invasive breast carcinoma. Soma Ghosh Karak et al.Conn Med.2010 Jan. 74(1):17-21

2. Perineural invasion as a risk factor for loco regional recurrence of invasive breast cancer.Narayan P, Flynn J, Zhang Z, Gillespie EF, Mueller B, Xu AJ, Cuaron J, McCormick B, Khan AJ, Cahlon O, Powell SN, Wen H, Braunstein LZ. Narayan P, et al. Sci Rep. 2021 Jun 17;11(1):12781. doi: 10.1038/s41598-02192343-4.Sci Rep.2021.PMID:34140615 Free PMC article

3. Issues relating to lymphovascular invasion in breast carcinoma. Hoda SA, Hoda RS, Merlin S, Shamonki J, Rivera M. Hoda SA, et al. Adv Anat Pathol. 2006 Nov;13(6):308-15. doi: 10.1097/01.pap.0000213048.69564.26. Adv Anat Pathol.2006.PMID: 17075296 Review

4. Mohammed RA, Martin SG, Mahmmod AM, et al. Objective assessment of lymphatic and blood vascular invasion in lymph nodenegative breast carcinoma: findings from a large case series with long-term follow-up. J Pathol. 2011;223:358-65.

5. Hoda SA, Brogi E, Koerner FC, Rosen PP. Rosen's breast pathology Philadelphia:Wolters Kluwer; 2014. [Google Scholar]

6. Duraker N, Caynak ZC, Turkoz K. Perineural invasion has no prognostic value in patients with invasive breast carcinoma. Breast. 2006;15:629-34. [PubMed] [Google Scholar]

7. McCready DR, Chapman JA, Hanna WM, et al. Factors affecting distant disease-free survival for primary invasive breast cancer: use of a log-normal survival model.Ann Surg Oncol.2000;7:4 16-26. [PubMed] [Google Scholar]

8. McCready DR, Chapman JA, Hanna WM, et al. Factors associated with local breast cancer recurrence after lumpectomy alone: postmenopausal patients. Ann Surg Oncol.2000; 7:562-7. [PubMed] [Google Scholar] 